\title{
Existence of the $r d l$ mutant alleles among the anopheles malaria vector in Indonesia
}

\author{
Puji BS Asih', Lepa Syahrani ${ }^{1}{ }^{1}$, Ismail EP Rozi ${ }^{1}$, Nandha R Pratama', Sylvia S Marantina ${ }^{1}$, Dian S Arsyad ${ }^{1,3}$, \\ Wibowo Mangunwardoyo ${ }^{2}$, William Hawley ${ }^{4,5}$, Ferdinand Laihad ${ }^{4}$, Shinta ${ }^{6}$, Supratman Sukowati ${ }^{6}$, Neil F Lobo ${ }^{7}$ \\ and Din Syafruddin ${ }^{1,3^{*}}$
}

\begin{abstract}
Background: The gamma-aminobutyric acid (GABA) receptor-chloride channel complex is known to be the target site of dieldrin, a cyclodiene insecticide. GABA-receptors, with a naturally occurring amino acid substitution, A302S/ $\mathrm{G}$ in the putative ion-channel lining region, confer resistance to cyclodiene insecticides that includes aldrin, chlordane, dieldrin, heptachlor, endrin and endosulphan.

Methods: A total of 154 mosquito samples from 10 provinces of malaria-endemic areas across Indonesia (Aceh, North Sumatra, Bangka Belitung, Lampung, Central Java, East Nusa Tenggara, West Nusa Tenggara, West Sulawesi, Molucca and North Molucca) were obtained and identified by species, using morphological characteristic. The DNA was individually extracted using chelex-ion exchanger and the DNA obtained was used for analyses using sequencing method.
\end{abstract}

Results: Molecular analysis indicated 11\% of the total 154 Anopheles samples examined, carried Rdl mutant alleles. All of the alleles were found in homozygous form. Rdl 3025 allele was observed in Anopheles vagus (from Central Java, Lampung, and West Nusa Tenggara), Anopheles aconitus (from Central Java), Anopheles barbirostris (from Central Java and Lampung), Anopheles sundaicus (from North Sumatra and Lampung), Anopheles nigerrimus (from North Sumatra), whereas the $302 \mathrm{G}$ allele was only found in Anopheles farauti from Molucca.

Conclusion: The existence of the Rdl mutant allele indicates that, either insecticide pressure on the Anopheles population in these areas might still be ongoing (though not directly associated with the malaria control programme) or that the mutant form of the Rdl allele is relatively stable in the absence of insecticide. Nonetheless, the finding suggests that integrated pest management is warranted in malaria-endemic areas where insecticides are widely used for other purposes.

Keywords: Anopheles, Diedrin, GABA, Receptor, Malaria, Rdl

\section{Background}

Malaria parasites in Indonesia are transmitted by 24 species of Anopheles mosquitoes [1] that vary markedly in biological attributes, including patterns of blood feeding, response to volatile insecticides, and larval habitats. Such variation will impact the effectiveness of insecticide-treated nets (ITNs), indoor residual spraying (IRS) and larval habitat treatments or modifications [2]. Malaria control strategies in Indonesia are aimed at the

\footnotetext{
* Correspondence: din@eijkman.go.id

'Eijkman Institute for Molecular Biology, Jalan Diponegoro, 69, Jakarta 10430, Indonesia

Full list of author information is available at the end of the article
}

Anopheles malaria vector and rapid treatment of patients $[3,4]$. Control of malaria vectors has been done using insecticides that target the immatures and adult stage $[5,6]$.

Vector control uses a group of organochlorine insecticides, organophosphates, pyrethroids, and carbamates to kill mosquitoes [7]. However, continuous use of insecticides at high frequency and over long periods without inadequate supervision selects for resistant strains of mosquitoes. This resistance causes a decrease in target susceptibility in the mosquito population with a reduction in the efficacy of the vector control programme. Currently, a total 125 species of mosquitoes, including

\section{Biomed Central}


the genus Anopheles have been recorded to be resistant to one or more insecticides [8].

Organochlorine insecticides are classified into three groups; dichlororodiphenyl trichlor ethane (DDT), hexachlorhexana $(\mathrm{HCH})$ and cyclodiene (aldrin, chlordane, heptachlor, dieldrin, endrin and endosulfan) [9]. DDT was used in malaria eradication programmes in Indonesia in the early 1950s but was subsequently banned in the 1970s as resistance to DDT emerged and spread rapidly. Dieldrin (cyclodiene) was introduced to malaria control programme in Indonesia since 1955 [10,11]. The use of dieldrin in health programmes proved to be highly effective and its use was promoted in agriculture [12]. The rapid development of mosquito resistance to this insecticide later prompted the national malaria control program to terminate the use of dieldrin in 1965. However, several cyclodiene compounds, such as endosulfan and endrin are currently still used as pesticide in Indonesia.

Mosquito resistance to insecticides has been detected in recent years following insecticide use. Some species of Anopheles have demonstrated resistance to dieldrin. Anopheles albimanus in El Salvador, Anopheles gambiae [13] and Anopheles sacharovi in Turkey [14] have shown resistance to DDT and dieldrin [15]. Khan (1961) reported multiple resistance to dieldrin and DDT in Aedes aegypti in Puerto Rico [16]. In Indonesia, double resistance to DDT and dieldrin has been reported through biochemical tests of Anopheles aconitus in Central Java [17].

Earlier, it was demonstrated that resistant traits depend on major genetic factors and that the nervous system of the resistant insect is more tolerant to the action of cyclodienes [18]. Ghiasuddin and Matsumura (1982) [19] first proposed that the GABA receptor is the target of these cyclodiene insecticides and this was later confirmed by others [20-22]. Resistance to dieldrin involves a subunit of the insect gamma aminobutyric acid (GABA) receptor, The encoded $R d l$ subunit assembles with other GABA receptor subunits to form the target site of the cyclodiene insecticides [23]. Dieldrin resistance is associated with the replacement of a single amino acid (alanine at position 302) in the Drosophila melanogaster $R d l$ allele [24]. A homologous mutation has also been indicated to confer dieldrin resistance in a wide variety of insect species such as A. aegypti, Drosophila simulans, Musca demestica, Lucilia cuprina, Blattella germanica, Tribolium castaneum, Hypothenemus hampei, Bemisia, and Myzus persicae. Resistance to dieldrin has been particularly associated with the single nucleotide polymorphisms in the M2 transmembrane domain of the GABA-gated chloride ion channel $(R d l$ allele) $[25,26]$. The present study aims to explore the allelic distribution of the $R d l$ gene among the
Anopheline malaria vectors from different malaria endemic areas of Indonesia.

\section{Methods}

\section{Study area of mosquito collection}

Female anopheline mosquitoes were collected from 10 provinces across Indonesia with different malaria area endemicities - Aceh, North Sumatra, Bangka Belitung, Lampung, Central Java, East Nusa Tenggara, West Nusa Tenggara, West Sulawesi, Molucca and North Molucca (Figure 1). After morphological identification to species, mosquitoes were stored individually in a $1.5 \mathrm{ml}$ Eppendorf microtube containing cotton flap and silica gel and kept at $4^{\circ} \mathrm{C}$ until use.

\section{Extraction of mosquito DNA}

Mosquitoes were ground with teflon pestles in $50 \mu \mathrm{l}$ blocking buffer (BB), containing $5.0 \mathrm{~g}$ Casein; $0.01 \mathrm{~g} / \mathrm{L}$ Phenol Red; 900 ml phosphate buffered saline (PBS), $\mathrm{pH}$ 7.4; $100 \mathrm{ml}$ of $0.1 \mathrm{~N} \mathrm{NaOH}$; with additional IGEPAL (5 ul IGEPAL: $1 \mathrm{ml} \mathrm{BB}$ ). The teflon pestles were subsequently rinsed with additional $200 \mu$ l volume of blocking buffer. Mosquito DNA from $50 \mu$ l homogenate was extracted using chelex-100 ion exchanger (Biorad Laboratories, Hercules, CA) essentially according to the procedure described previously [27]. The remaining 200 $\mu l$ homogenate was used for other analysis. The DNA was either used immediately for a polymerase chain reaction (PCR) or stored at $-20^{\circ} \mathrm{C}$ for later analysis.

\section{Gene amplification with the seminested-PCR}

Semi-nested PCRs were performed on the $R d l$ gene. All reactions were carried out in $25 \mu \mathrm{l}$ reaction mixtures containing $50 \mathrm{mM} \mathrm{KCl}, 10 \mathrm{mM}$ Tris- $\mathrm{HCl} \mathrm{pH} \mathrm{8.3,} 1.5$ $\mathrm{mM} \mathrm{MgCl} 2,200 \mathrm{mM}$ dNTP, 1 U Taq Polymerase and a

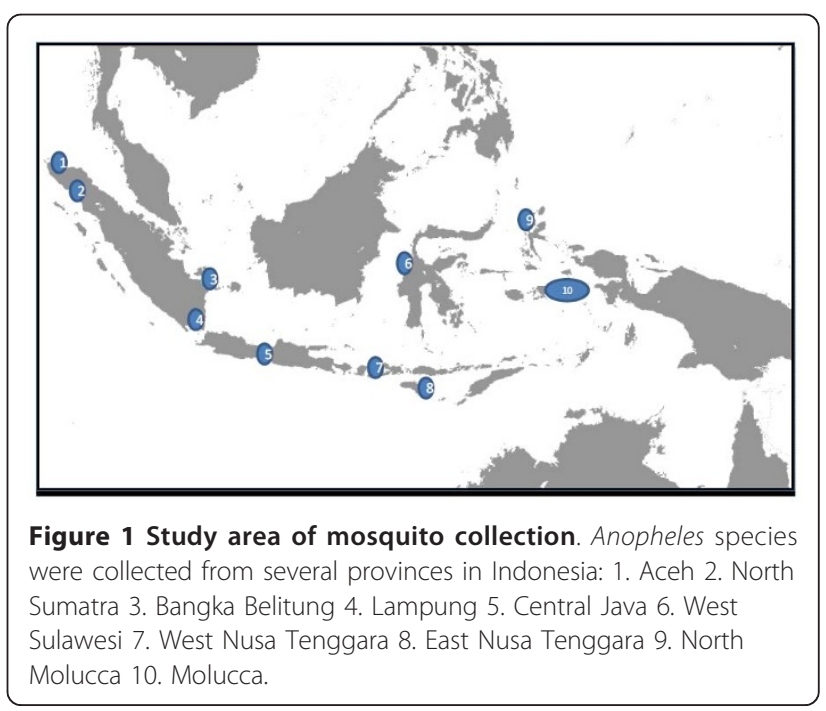


pair of primers (20 pM each). 1-5 $\mu$ l of DNA was used as template in the first reaction and 1-2 $\mu$ l of the first round PCR product was used as template for the secondary PCR. Secondary PCR products were resolved by electrophoresis on $2 \%$ agarose gel and visualized by staining with ethidium bromide. The $R d l$ gene was amplified using primers RDLF F10 (5 'SAG TTT TCG ATG CGT GTA TAT GGT WW 3'), F11 RDLF (5 'AGC ATG TGA AAT TTK ASA G 3 '), and R12 RDLF (5’ CCA CAA ATA GCA TGG GAC CCA RGA 3 '). The initial nucleotide $S$ is $C / G, W$ is $T / A, K$ is $T / G$, and $\mathrm{R}$ is $\mathrm{A} / \mathrm{G}$. Cycling conditions for first PCR using oligos F11 $\times$ R12 RDLF was denaturation at $94^{\circ} \mathrm{C}$, annealing at $50^{\circ} \mathrm{C}$, extension at extension at $72^{\circ}$ and final polymerization at $72^{\circ} \mathrm{C}$, each phase lasts for $30 \mathrm{~s}, 30 \mathrm{~s}, 1 \mathrm{~min}$ and 30 $\mathrm{s}$, and $5 \mathrm{~min}$ to 30 cycles. The second round PCR conditions used oligos F10 $\times$ F12 RDLF for the stages of denaturation, annealing, extension, and final polymerization are $94^{\circ} \mathrm{C}, 50^{\circ} \mathrm{C}, 72^{\circ} \mathrm{C}$, and $72^{\circ} \mathrm{C}$, each phase lasts for $30 \mathrm{~s}$, $30 \mathrm{~s}, 45 \mathrm{~s}$ and $45 \mathrm{~s}$ (40 cycles). The final PCR products of approximately $250 \mathrm{bp}$ in size were sequenced in all individual mosquitoes. The PCR products were purified using PCR clean up system (PROMEGA Corporation, Madison, WI, USA). The purified amplicons were sequenced using an ABI Prism ${ }^{\mathrm{TM}}$ Dye BigDye Terminator Cycle Sequencing Ready Kit (Applied Biosystem, Foster City, USA) in automatic sequencer fluorescent DNA capillary electrophoresis $(\mathrm{ABI} 3130 \times 1)$ at the Eijkman Institute, Jakarta, Indonesia.

\section{Results}

PCR amplification and DNA sequencing of the fragment of $r d l$ gene of various anopheles species from Indonesia Using primers that has been designed based on the published sequence of $R d l$ gene from An. gambiae (GenBank acc no. AF470112 and AF470116), Anopheles stephensi (GenBank acc no. EU883213), Aedes aegypti (GenBank acc no. AAU28803), and Culex quinquefasciatus (GenBank acc no. XM001850045) and sequences of Anopheles sundaicus from Indonesia (GenBank acc no. JN675907JN675923), encompasssing the $R d l$ gene mutation site was successfully amplified and amplicons of approximately $250 \mathrm{bp}$ in size in 19 Anopheles species were obtained. Amplicons were then sequenced and submitted to GenBank acc no. JN690008 - JN690025. Alignment of the 207 bp DNA sequencing results of each species is shown in Figure 2. The DNA sequences of the $R d l$ gene showed 12 variable nucleotide sites among the Anopheles species analyzed but the deduced amino acid sequences indicated a high sequence conservation.

\section{Existence of rdl allele}

Analysis of DNA sequences of 154 amplicons representing 19 Anopheles species indicated that the majority of

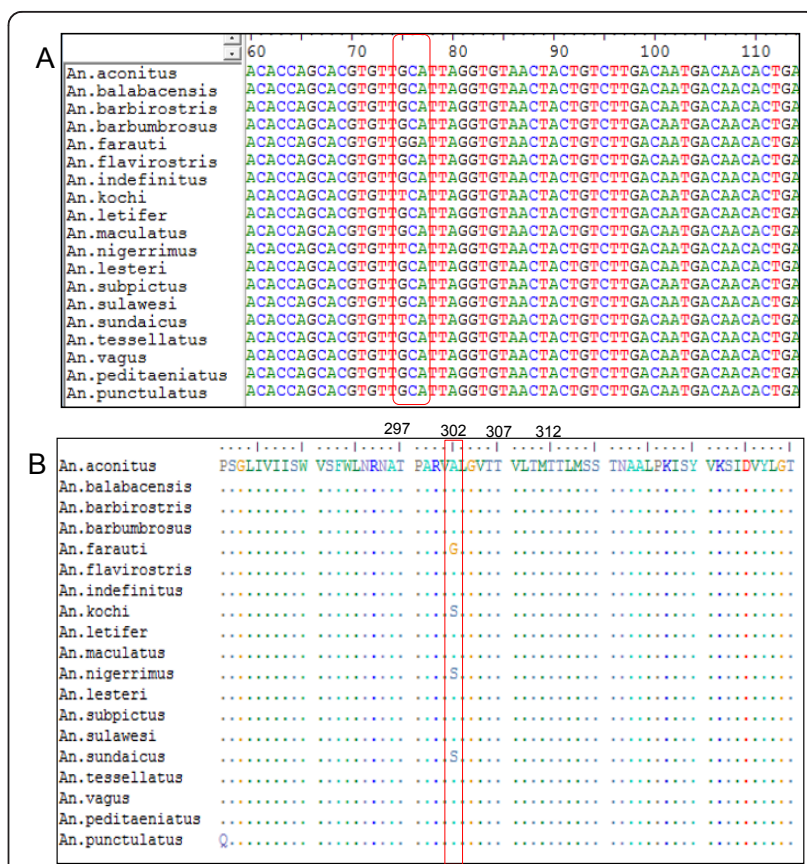

Figure 2 Sequence aligment. a. DNA sequence aligment of the fragment of Rdl gene in 19 various Anopheles species from Indonesia; b. Amino acid sequences of the GABA receptor encoded by Rdl gene encompassing the mutation site, codon A302S/G in 19 various Anopheles species from Indonesia. Numbers indicate the codon in GABA receptor.

the Anopheles carried the wildtype 302A allele. The $302 \mathrm{~S}$ polymorphism of the $R d l$ gene, popularly known as $R d l$ allele was detected in four provinces: North Sumatra, Central Java, Lampung and West Nusa Tenggara while the $302 \mathrm{G}$ allele was detected in Molucca Province (Table 1). The $R d l$ allele was detected in Anopheles vagus, An. aconitus, Anopheles barbirostris, Anopheles sundaicus and Anopheles nigerrimus whereas the 302 G allele was only detected in Anopheles farauti from Molucca (Figure 3). All of the alleles were found in homozygous form. The $R d l$ 302S/G allele was not found in any of the Anopheles species examined from Aceh, Bangka Belitung, West Sulawesi, East Nusa Tenggara and North Molucca.

\section{Frequency distribution of the $r d$ l allele}

In this report, the frequency distribution of the $R d l$ allele in each species examined could not be determined as many of them were represented by an individual sample. In Central Java and Lampung Provinces, however, it was evident that An.s vagus, An. aconitus and An.s barbirostris represent the species with the higher $R d l$ mutant allele frequency, respectively. The three species are well known to closely associate with agriculture area as mostly use rice field or stream in inland area as their breeding sites. 
Table 1 Frequency of $R d l$ allele in each Anopheles species examined at each study site

\begin{tabular}{|c|c|c|c|c|c|c|c|c|}
\hline \multirow[t]{2}{*}{ Study site Provinces } & \multirow[t]{2}{*}{ Species } & \multirow{2}{*}{$\stackrel{N}{\Sigma}=154$} & \multicolumn{3}{|c|}{ Genotype frequency $\%$} & \multicolumn{3}{|c|}{ Allele frequency(\%) } \\
\hline & & & AA & SS & GG & A & $S$ & G \\
\hline \multirow[t]{8}{*}{ North Molluca } & An. punctulatus & 2 & 100 & 0 & 0 & 100 & 0 & 0 \\
\hline & An. subpictus & 1 & 100 & 0 & 0 & 100 & 0 & 0 \\
\hline & An. tesselatus & 1 & 100 & 0 & 0 & 100 & 0 & 0 \\
\hline & An. kochi & 3 & 100 & 0 & 0 & 100 & 0 & 0 \\
\hline & An. barbumbrosus & 1 & 100 & 0 & 0 & 100 & 0 & 0 \\
\hline & An. farauti & 1 & 100 & 0 & 0 & 100 & 0 & 0 \\
\hline & An. lesteri & 1 & 100 & 0 & 0 & 100 & 0 & 0 \\
\hline & An. vagus & 3 & 100 & 0 & 0 & 100 & 0 & 0 \\
\hline \multirow[t]{3}{*}{ Molluca } & An. punctulatus & 4 & 100 & 0 & 0 & 100 & 0 & 0 \\
\hline & An. lesteri & 1 & 100 & 0 & 0 & 100 & 0 & 0 \\
\hline & An. farauti & 10 & 90 & 0 & 10 & 90 & 0 & 10 \\
\hline \multirow[t]{4}{*}{ North Sumatra } & An. vagus & 4 & 100 & 0 & 0 & 100 & 0 & 0 \\
\hline & An. peditaeniatus & 1 & 100 & 0 & 0 & 100 & 0 & 0 \\
\hline & An. nigerrimus & 3 & 67 & 33 & 0 & 67 & 33 & 0 \\
\hline & An. sundaicus & 8 & 87.5 & 12.5 & 0 & 87.5 & 12.5 & 0 \\
\hline \multirow[t]{5}{*}{ Central Java } & An. vagus & 4 & 50 & 50 & 0 & 50 & 50 & 0 \\
\hline & An. aconitus & 11 & 55.5 & 45.5 & 0 & 55.5 & 45.5 & 0 \\
\hline & An. barbirostris & 8 & 75 & 25 & 0 & 75 & 25 & 0 \\
\hline & An. Maculatus & 1 & 100 & 0 & 0 & 100 & 0 & 0 \\
\hline & An. balabacensis & 6 & 100 & 0 & 0 & 100 & 0 & 0 \\
\hline \multirow[t]{3}{*}{ Lampung } & An. vagus & 5 & 60 & 40 & 0 & 60 & 40 & 0 \\
\hline & An. sundaicus & 23 & 96 & 4 & 0 & 96 & 4 & 0 \\
\hline & An. barbirostris & 1 & 0 & 100 & 0 & 0 & 100 & 0 \\
\hline \multirow[t]{2}{*}{ Bangka Belitung } & An. sundaicus & 10 & 100 & 0 & 0 & 100 & 0 & 0 \\
\hline & An. letifer & 3 & 100 & 0 & 0 & 100 & 0 & 0 \\
\hline \multirow[t]{9}{*}{ East Nusa tenggara } & An. vagus & 1 & 100 & 0 & 0 & 100 & 0 & 0 \\
\hline & An. sundaicus & 2 & 100 & 0 & 0 & 100 & 0 & 0 \\
\hline & An. subpictus & 4 & 100 & 0 & 0 & 100 & 0 & 0 \\
\hline & An. flavirostris & 2 & 100 & 0 & 0 & 100 & 0 & 0 \\
\hline & An. indefinitus & 3 & 100 & 0 & 0 & 100 & 0 & 0 \\
\hline & An. barbirostris & 1 & 100 & 0 & 0 & 100 & 0 & 0 \\
\hline & An. tesselatus & 1 & 100 & 0 & 0 & 100 & 0 & 0 \\
\hline & An. kochi & 1 & 100 & 0 & 0 & 100 & 0 & 0 \\
\hline & An. maculatus & 1 & 100 & 0 & 0 & 100 & 0 & 0 \\
\hline West Nusa & An. vagus & 5 & 80 & 20 & 0 & 80 & 20 & 0 \\
\hline \multirow[t]{2}{*}{ Tenggara } & An. subpictus & 5 & 100 & 0 & 0 & 100 & 0 & 0 \\
\hline & An. sundaicus & 4 & 100 & 0 & 0 & 100 & 0 & 0 \\
\hline Aceh & An. maculatus & 2 & 100 & 0 & 0 & 100 & 0 & 0 \\
\hline \multirow[t]{4}{*}{ West Sulawesi } & An. barbirostris & 3 & 100 & 0 & 0 & 100 & 0 & 0 \\
\hline & An. sulawesi & 1 & 100 & 0 & 0 & 100 & 0 & 0 \\
\hline & An. peditaeniatus & 1 & 100 & 0 & 0 & 100 & 0 & 0 \\
\hline & An. nigerrimus & 1 & 100 & 0 & 0 & 100 & 0 & 0 \\
\hline
\end{tabular}




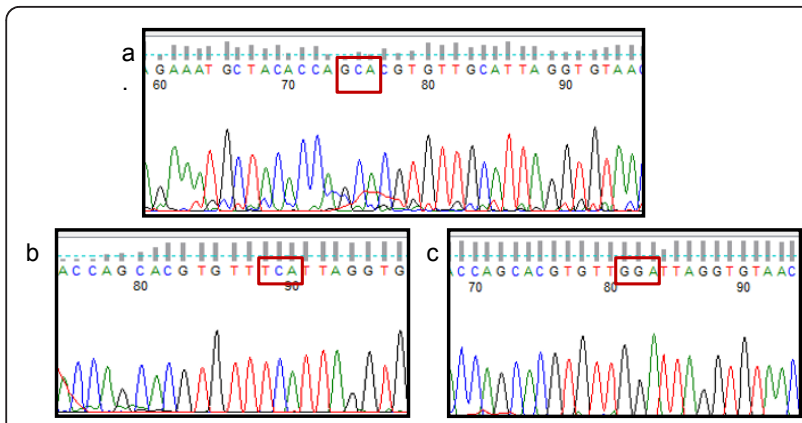

Figure 3 Electropherogram of the DNA sequencing of GABA$R d l$ gene. a. indicated the wildtype allele and b. indicated the resistance alele GCA. (alanin) replacement by TCA (serine) and c. GCA replacement by GGA (glycine).

\section{Discussion}

The $R d l$ gene fragment encompassing the mutational sites associted with dieldrin resistance has been successfully amplified and sequenced in 19 species of Anopheline mosquitoes in indonesia and the DNA sequences have been deposited in the GenBank. Molecular analyses of the $R d l$ gene of the Anopheles malaria vectors collected in 10 endemic areas of Indonesia: Aceh, North Sumatra, Bangka Belitung, Lampung, Central Java, East Nusa Tenggara, West Nusa Tenggara, West Sulawesi, Molucca and North Molucca indicated a high sequence conservation at the protein levels to the previously published $R d l$ sequence [25]. The existence of the resistant $R d l$ allele in five provinces - the $R d l 302 \mathrm{~S}$ in four provinces: North Sumatra, Lampung, Central Java and West Nusa Tenggara, among An. vagus, An. aconitus, An. barbirostris, An. sundaicus and An. nigerrimus and the Rdl302G in the An. farauti in Molucca Province, was revealed. This finding indicates that cyclodiene insecticides pressures along this specific target in anopheline mosquitoes are still in place in many malaria-endemic areas of Indonesia. Cyclodiene insecticides were used in malaria control programmes during the 1955 following the spread of mosquito resistance to DDT, and so far, dieldrin was the only cyclodiene insecticide that had been used in the programme in Indonesia This insecticide was used only for a short period following the discovery of doubly-resistant An. aconitus to DDT and dieldrin in Central Java in 1965 [16]. However, in agricultural areas, several cyclodiene insecticides are currently still in use such as, endosulfan, aldrin and heptachlor, and resistance of these insecticides by various agricultural insects has been documented in several areas [28].

Although the resistence to dieldrin had been first documented in An. aconitus, in Central Java in 1965, this finding is the first report of the existence of the $R d l$ dieldrin-resistant alleles, A302A/G in Indonesian
Anopheline vectors. As dieldrin is no longer used in Indonesia, the existence of $R d l$ mutant allele in many Anopheles species in Indonesia might be associated with either the use of cyclodiene insecticides in agriculture or the relative high fitness of the mutant alleles in comparison to the wildtype.

In conclusion, this study reports the the existence of the $R d l$ mutant alleles among the major malaria vectors in Indonesia and their existence might be associated with insecticide use in agricultural area. Further biochemical study to assess the sensitivity of the Anopheles that carries the $R d l$ allele to the cyclodiene insecticides used in agriculture are now in progress.

\section{Acknowledgements}

The authors are grateful for the support of the Eijkman Institute Jakarta, UNICEF Jakarta the National Institute of Health research and Development, Department of Health Jakarta, all colleagues from MTC Indonesia, CDCEnvironmental Health and Sumba SPIRIT Team, East Nusa Tenggara Province. The authors wish to thank Nia Rahmawati, Sully Kosasih, Suradi, Anggi P Nurhidayati, Siti Zubaidah from Eijkman Institute for their help in malaria laboratory and health professional staff for their assistance during sample collection in each area.

This study was supported by the GATES Foundation through Malaria Transmission Consortium Indonesia and Sumba SPIRIT Study and Indonesia Government.

\section{Author details}

'Eijkman Institute for Molecular Biology, Jalan Diponegoro, 69, Jakarta 10430, Indonesia. ${ }^{2}$ Department of Biology, Faculty of Mathematic and Science, University of Indonesia, Depok 16424, Indonesia. ${ }^{3}$ Department of Parasitology, Faculty of Medicine, Hasanuddin University, Makassar 90245, Indonesia. ${ }^{4}$ UNICEF, Jakarta, 12920, Indonesia. ${ }^{5}$ Center for Communicable Diseases Control and Prevention (CDC), Atlanta, USA. ${ }^{6}$ Health Ecology Research \& Development Centre, National Institute of Health, Research and Development, Department of Health, Jalan Percetakan Negara 29, Jakarta, 10560, Indonesia. ${ }^{7}$ Eck Institute for Global Health, University of Notre Dame, Notre Dame, IN, USA.

\section{Authors' contributions}

DS, LS, PBSA, IEPR, NRP, SSM, S, WM and DSA performed molecular assays, data analysis, and the manuscript writing. PBSA and LS have equal contribution for this study. SS, S collected field samples and performed data analysis. DS, SS, FL, NFL, and WH designed the study and manuscripts writing were responsible for management and fund raising for this study. All authors read and approved the manuscript. This study is part of the thesis for Master of Science Programme at the University of Indonesia for LS.

\section{Competing interests}

The authors declare that they have no competing interests.

Received: 23 November 2011 Accepted: 25 February 2012

Published: 25 February 2012

\section{References}

1. [http://www.pppl.depkes.go.id/_asset/_download/ Buku_saku_menuju_eliminasi_malaria.pdf].

2. Bangs MJ, Annis BA, Bahang ZH, Hamzah N, Arbani PR: Insecticide susceptibility status of Anopheles koliensi (Diptera: Culicidae) in northeastren irian Jaya. Indonesia Southeast Asian J Trop Med Public 1993, 24:357-362.

3. Ministry of Health, Indonesia: Bersama kita berantas malaria. [http://www. depkes.go.id/index.php/berita/press-release/1055-bersama- kita-berantasmalaria.pdf].

4. Kandun IN: Emerging disease in Indonesia: control and challenges. Tropical Medicine and Health 2006, 34(4):141-147. 
5. Gunawan S: Epidemiologi Malaria. Malaria: Epidemiologi, Patogenesis, Manifestasi Klinis dan Penanganan. 2000 edition. Jakarta: Penerbit Buku Kedokteran; 1999, 1-16.

6. Harijanto PN: Malaria: dari Molekuler ke Klinis Jakarta: EGC; 2008.

7. ffrench-Constant RH, Pittendrigh B, Vaughan A, Anthony N: Why are there so few resistance-associated mutations in insecticide target genes? Philos Trans R Soc Lond B Biol Sci 1998, 353:1685-1693.

8. Centres for Disease Control and Prevention: Anopheles Mosquitoes. [http:// www.cdc.gov/malaria/biology/mosquito].

9. World Health Organization Eastern Mediterranean Region: Monitoring of insecticide resistance in malaria vector Cairo-Egypt: WHO

10. Soerono M, Badawi AS, Muir DA, Soedono A, Siran M: Observations on doubly resistant Anopheles aconitu Donitz in Java, Indonesia, and on its amenability to treatment with malathion. Bull World Health Organ 1965, 33:453-459.

11. Hayes WJ: The Toxicity of dieldrin to man: Report on a survey. Bull World Health Organ 1959, 20:891-912.

12. Zavon MR: MD, FAPHA, Hamman RE: Human experience with dieldrin in malaria control programs. Am J Public Health 1961, 51:1026-1034.

13. Haridi AM: Linkage studies on DDT and dieldrin resistance in species $A$ and species B of the Anopheles gambia complex. Bull World Health Organ 1974, 50:441-448.

14. de Zulueta J: Insecticide resistance in Anopheles sacharov. Bull World Health Organ 1959, 20:797-822.

15. Davidson G: DDT resistance and dieldrin resistance in Anopheles albimanu. Bull World Health Organ 1993, 28:25-33.

16. Khan NA, Brown AWA: Genetical studies on dieldrin resistance in Aedes aegypt and its cross resistance to DDT. Bull World Health Organ 1961, 24:519-526.

17. Soerono M, Davidson G, Muir DD: The development and trend of insecticide-resistance in Anopheles aconitu Donits and Anopheles sundaicu Rodenwaldt. Bull World Health Organ 1965, 32:161-168.

18. Brown AWA: Mechanism of resistance againts insecticides. Ann Rev Entomol 1960, 5:301-326

19. Ghiasuddin SM, Matsumura F: Inhibition of gamma-aminobutyric acid (GABA)-induced chloride uptake by gamma-BHC and heptachlor epoxide. Comp Biochem Physiol 1982, 73:141-144.

20. Lawrence LJ, Casida JE: Stereospesific action of pyrethroid insecticides on the $\gamma$-aminobutyric acid receptor-ionophore complex. Science 1983, 221:1399-1401.

21. Tanaka K, Matsumura F: Altered picrotoxinin receptor as a cause for cyclodiene resistance in Musca domestica, Aedes aegypti and Blatella germanica in membrane receptors and enzyme as targets of insecticide action New York: Plenum Press; 1986.

22. Thompson M, Shotkoski F, Constant RF: Cloning and sequencing of the cyclodiene insecticide resistance gene from the yellow fever mosquito Aedes aegypti conservation of the gene and resistance associated mutation with Drosophila. FEBS Lett 1993, 325:187-190.

23. ffrench-Constant RH, Anthony N, Aronstein K, Rocheleau T, Stilwell G: Cyclodiene insecticide resistance: from molecular to population genetics. Ann Rev Entomol 2000, 48:449-466.

24. ffrench-Constant RH, Rocheleau TA, Steichen JC, Chalmers AE: A point mutation in a Drosophila GABA receptor confers insecticide resistance. Nature 1993, 363:449-451

25. Buckingham SD, Biggin PC, Satelle BM, Brown LA, Satelle DB: Insect GABA receptors: Splicing, editing, and targeting by antiparasitics and insecticides. Mol Pharmacol 2005, 68:942-951.

26. Li A, Yang Y, Wu S, Li C, Wu Y: Investigation of resistance mechanism to fipronil in diamonback moth (Lepidoptera: Plutellidae). J Econ Entomol 2006, 99:914-919.

27. Wooden J, Kyes S, Sibley CH: PCR and strain identification in Plasmodium falciparu. Parasitol Today 1993, 9:303-305.

28. Hadiyani S, Sunarto DA, Sujak, Wakhidah N: Resistensi Helicoverpa armigera (Hubner) terhadap insektisida di daerah pengembangan kapas lamongan. Prosiding Lokaraya Agribisnis 2008, X:166.

doi:10.1186/1475-2875-11-57

Cite this article as: Asih et al.: Existence of the $r d l$ mutant alleles among the anopheles malaria vector in Indonesia. Malaria Journal 2012 11:57.

\section{Submit your next manuscript to BioMed Central and take full advantage of:}

- Convenient online submission

- Thorough peer review

- No space constraints or color figure charges

- Immediate publication on acceptance

- Inclusion in PubMed, CAS, Scopus and Google Scholar

- Research which is freely available for redistribution

Submit your manuscript at www.biomedcentral.com/submit 